NASA/CR—2006-214388

\title{
Heat Rejection Concepts for Lunar Fission Surface Power Applications
}

John Siamidis

Analex Corporation, Brook Park, Ohio 


\section{NASA STI Program . . . in Profile}

Since its founding, NASA has been dedicated to the advancement of aeronautics and space science. The NASA Scientific and Technical Information (STI) program plays a key part in helping NASA maintain this important role.

The NASA STI Program operates under the auspices of the Agency Chief Information Officer. It collects, organizes, provides for archiving, and disseminates NASA's STI. The NASA STI program provides access to the NASA Aeronautics and Space Database and its public interface, the NASA Technical Reports Server, thus providing one of the largest collections of aeronautical and space science STI in the world. Results are published in both non-NASA channels and by NASA in the NASA STI Report Series, which includes the following report types:

- TECHNICAL PUBLICATION. Reports of completed research or a major significant phase of research that present the results of NASA programs and include extensive data or theoretical analysis. Includes compilations of significant scientific and technical data and information deemed to be of continuing reference value. NASA counterpart of peer-reviewed formal professional papers but has less stringent limitations on manuscript length and extent of graphic presentations.

- TECHNICAL MEMORANDUM. Scientific and technical findings that are preliminary or of specialized interest, e.g., quick release reports, working papers, and bibliographies that contain minimal annotation. Does not contain extensive analysis.

- CONTRACTOR REPORT. Scientific and technical findings by NASA-sponsored contractors and grantees.
- CONFERENCE PUBLICATION. Collected papers from scientific and technical conferences, symposia, seminars, or other meetings sponsored or cosponsored by NASA.

- SPECIAL PUBLICATION. Scientific, technical, or historical information from NASA programs, projects, and missions, often concerned with subjects having substantial public interest.

- TECHNICAL TRANSLATION. Englishlanguage translations of foreign scientific and technical material pertinent to NASA's mission.

Specialized services also include creating custom thesauri, building customized databases, organizing and publishing research results.

For more information about the NASA STI program, see the following:

- Access the NASA STI program home page at http://www.sti.nasa.gov

- E-mail your question via the Internet to help@sti.nasa.gov

- Fax your question to the NASA STI Help Desk at 301-621-0134

- Telephone the NASA STI Help Desk at 301-621-0390

- Write to:

NASA STI Help Desk

NASA Center for AeroSpace Information 7121 Standard Drive Hanover, MD 21076-1320 


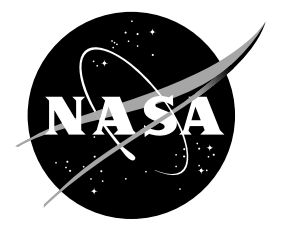

\section{Heat Rejection Concepts for Lunar Fission Surface Power Applications}

John Siamidis

Analex Corporation, Brook Park, Ohio

Prepared for the

Fourth International Energy Conversion Engineering Conference and Exhibit (IECEC) sponsored by the American Institute of Aeronautics and Astronautics San Diego, California, June 26-29, 2006

Prepared under Contract NAS3-00145

National Aeronautics and

Space Administration

Glenn Research Center

Cleveland, Ohio 44135 


\section{Acknowledgments}

The work described in this paper was performed for the NASA Exploration Systems Mission Directorate and the Prometheus Nuclear Systems and Technology Program.

This report contains preliminary findings, subject to revision as analysis proceeds.

Trade names and trademarks are used in this report for identification only. Their usage does not constitute an official endorsement, either expressed or implied, by the National Aeronautics and Space Administration.

Level of Review: This material has been technically reviewed by expert reviewer(s).

Available from

NASA Center for Aerospace Information 7121 Standard Drive

Hanover, MD 21076-1320
National Technical Information Service 5285 Port Royal Road Springfield, VA 22161 


\title{
Heat Rejection Concepts for Lunar Fission Surface Power Applications
}

\author{
John Siamidis \\ Analex Corporation \\ Brook Park, Ohio 44142
}

\begin{abstract}
This paper describes potential heat rejection design concepts for lunar surface Brayton power conversion systems. Brayton conversion systems are currently under study by NASA for surface power applications. Surface reactors may be used for the moon to power human outposts enabling extended stays and closed loop life support. The Brayton Heat Rejection System (HRS) must dissipate waste heat generated by the power conversion system due to inefficiencies in the thermal-to-electric conversion process. Space Brayton conversion system designs tend to optimize at efficiencies of about 20 to 25 percent with radiator temperatures in the $400 \mathrm{~K}$ to $600 \mathrm{~K}$ range. A notional HRS was developed for a $100 \mathrm{kWe}$-class Brayton power system that uses a pumped water heat transport loop coupled to a water heat pipe radiator. The radiator panels employ a tube and fin construction consisting of regularlyspaced circular heat pipes contained within two composite facesheets. The water heat pipes interface to the coolant through curved sections partially contained within the cooling loop. The paper evaluates various design parameters including radiator panel orientation, coolant flow path, and facesheet thickness. Parameters were varied to compare design options on the basis of $\mathrm{H}_{2} \mathrm{O}$ pump pressure rise and required power, heat pipe unit power and radial flux, radiator area, radiator panel areal mass, and overall HRS mass.
\end{abstract}

\section{Nomenclature}

$T \quad$ Temperature $(\mathrm{K})$

$\Delta P \quad$ Pressure Drop $(\mathrm{kPa})$

$f \quad$ Friction Factor

$L \quad$ Length (m)

$d \quad$ Diameter $(\mathrm{m})$

$u \quad$ Velocity $(\mathrm{m} / \mathrm{s})$

$\rho \quad$ Liquid Density $\left(\mathrm{kg} / \mathrm{m}^{3}\right)$

\section{Introduction}

Fission Surface Power Systems (FSPS) are of current interest because surface reactors may be used on the moon, (see fig. 1). Potential applications include providing power for human outposts to enable extended stays, as well as powering in-situ resource utilization and closed loop life support systems. The reactor power system consists of the reactor, power conversion, heat rejection, and power management and distribution subsystems. Closed Brayton Cycle (CBC) converters are one of several promising options for power conversion within a reactor power system. The Heat Rejection System (HRS) must dissipate waste heat generated by the Power Conversion System (PCS) due to inefficiencies in the thermal-to-electric conversion process. Brayton systems tend to optimize at efficiencies of about 20 to 25 percent with radiator temperatures in the $400 \mathrm{~K}$ to $600 \mathrm{~K}$.

Previous design studies examined a possible heat rejection concept for a $100 \mathrm{kWe}$ Brayton PCS for the proposed Jupiter Icy Moons Orbiter (JIMO) mission (ref. 1). This paper uses the previous design concept as a starting point for the definition of the FSPS Brayton HRS. The HRS consists of a pumped water heat transport loop coupled to a water heat pipe radiator. The radiator area is distributed across two planar panels. The radiator panels provide singlesided heat rejection for the horizontal configuration and two-sided heat rejection for the vertical configuration as shown in figure 2.

The PCS includes two Brayton converters to produce the total net output power. Two Braytons could be operated at 50 percent or one Brayton operated at 100 percent with the second serving as a redundant spare. The Braytons reject heat through a gas cooler to the HRS radiators. The HRS accepts heat from the Brayton power converters and rejects it into space through the radiator panels. A water cooling loop connects the Brayton converters to the radiator panels. 


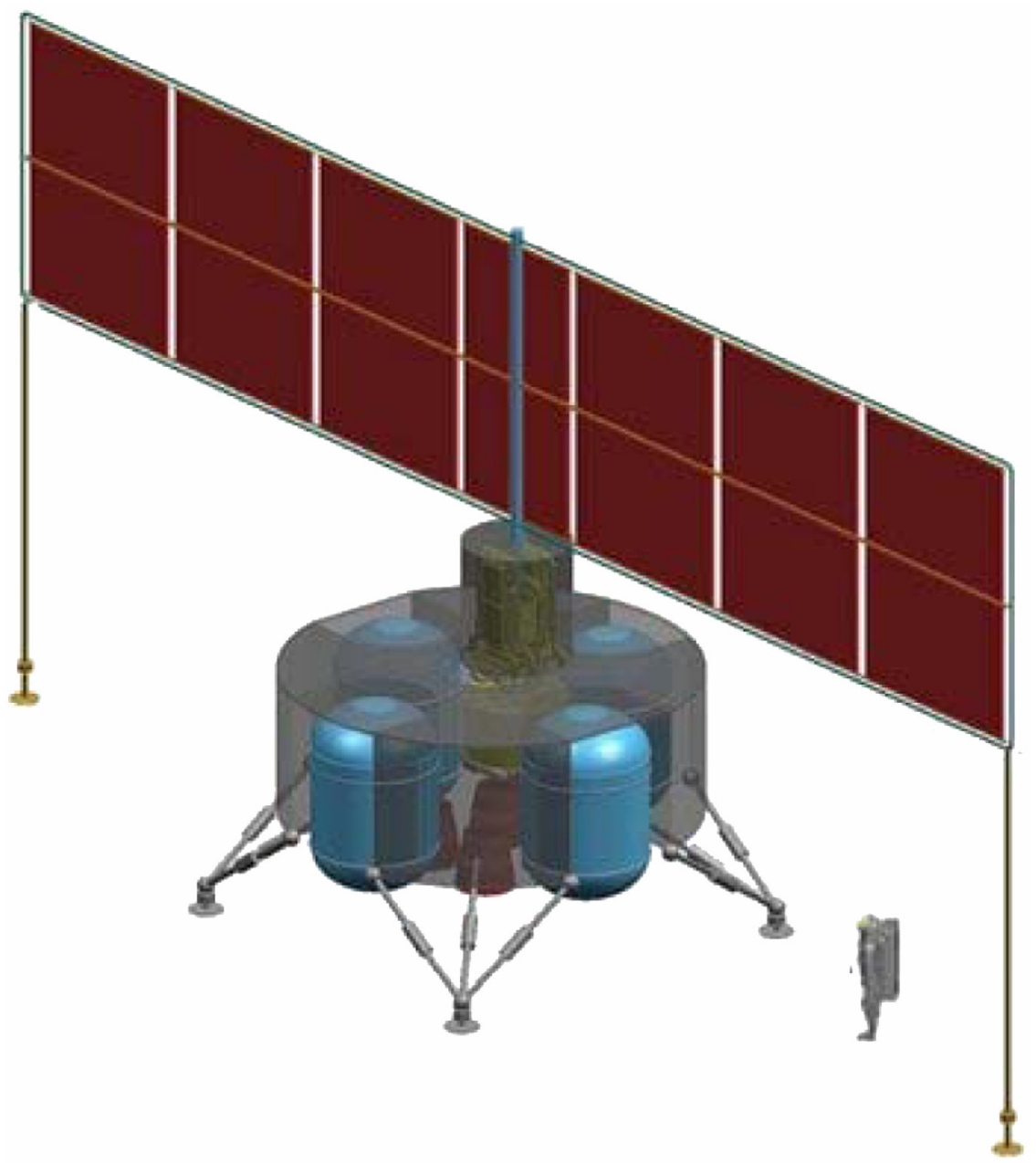

Figure 1.-Lunar FSPS. 

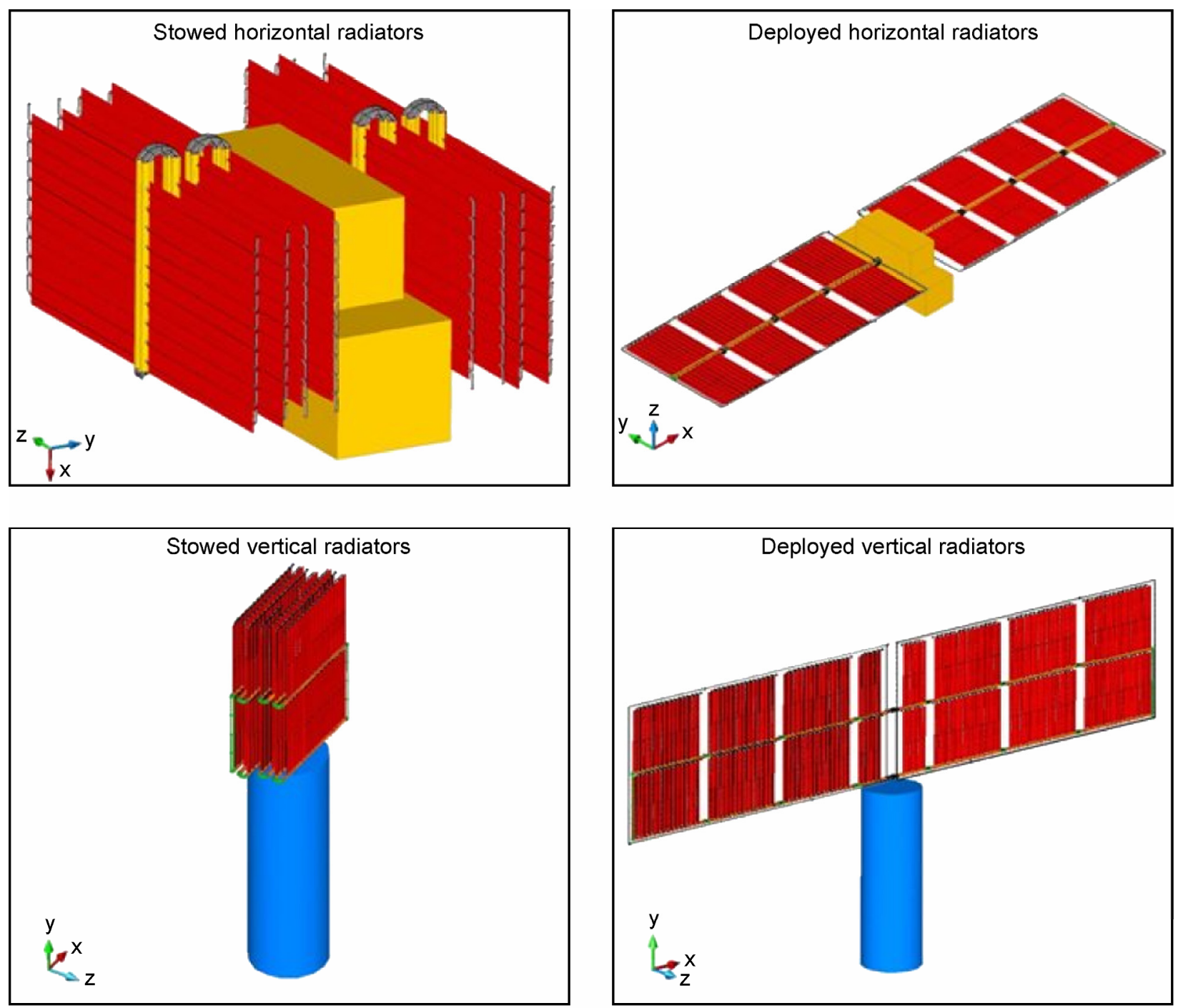

Figure 2.-FSPS HRS horizontal and vertical configurations.

\section{HRS Design Basis}

Two radiator panel designs were considered in the trade study, as shown in figure 3. In both designs the radiator panels use a construction consisting of regularly-spaced circular heat pipes contained within two composite facesheets. In the first design, the heat pipes are thermally connected to the facesheets through a square saddle extending along the entire axial length of the heat pipe, and a low density filler material is used between the facesheets for panel structural integrity. In the second design the heat pipes are thermally connected to the facesheets through a cylindrical saddle extending along the entire axial length of the heat pipe and there is no filler material between the facesheets. The second design was assumed for this trade study.

The heat pipes use water as the working fluid in a titanium envelope. Heat pipes provide an efficient means of spreading the heat across the radiator surface with minimal temperature drop. The high conductivity composite facesheets serve as the radiator fin.

The radiator has a central manifold that separates the panel into two equal halves, as shown in figure 4 . This allows the radiator to utilize more conventional and reasonable length heat pipes. For this paper a heat pipe length of two meters was assumed, which resulted in a radiator fixed width of just over four meters. The length of the radiator was subsequently varied to yield the necessary total area and accommodate the various heat loads. 


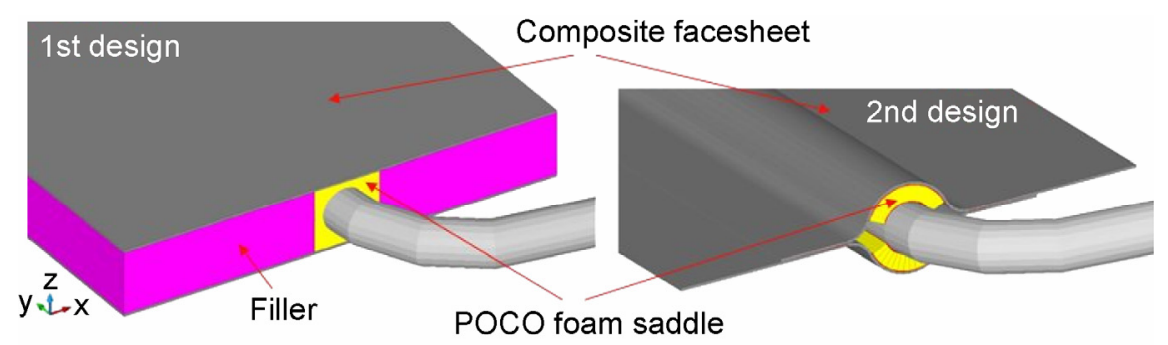

Figure 3.-Radiator panel design.

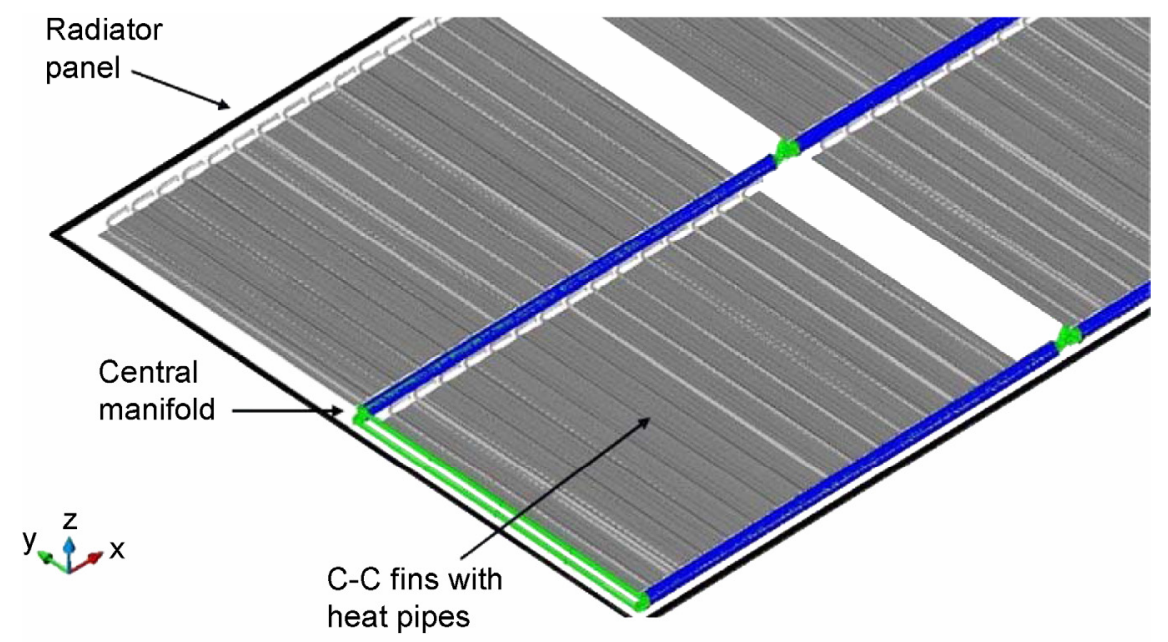

Figure 4.-Radiator detail.

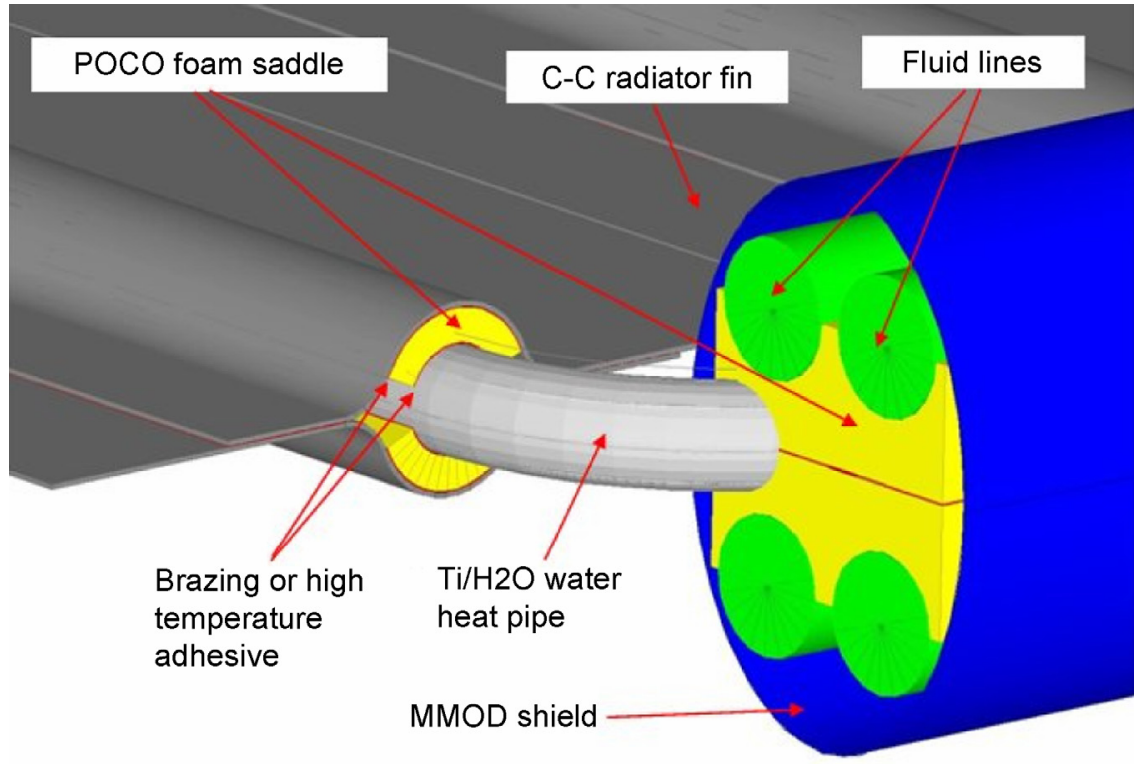

Figure 5.-Radiator heat pipe integration with cooling loop.

Figure 5 shows how the heat pipe radiator is integrated with the pumped water cooling loop. The POCO (POCO Graphite, Inc.) foam saddle provides compliance to permit fin-heat pipe thermal expansion and a degree of micrometeoroid shielding. The heat pipe-to-saddle and saddle-to-facesheet bond is accomplished through brazing or high temperature adhesive. One of the key advantages to this type of radiator is its ability to withstand damage from micrometeoroid and orbital debris (MMOD). A fatal MMOD impact to a single heat pipe, even though it will result in the failure of that heat pipe, would have minimal system performance impact. 
The water heat pipes interface to the coolant through curved sections partially contained within the cooling loop. The heat pipe evaporators are "sandwiched" between two cooling loops. One loop is active and the second is the backup. A POCO foam saddle is provided between the heat pipe evaporators and the cooling loop ducts to improve heat transfer. The two HRS fluid loops provide fault tolerance against loss of either a PCS unit or HRS fluid loop without affecting power generating capabilities. The fluid ducting is made of titanium. The duct cross-section is split circular as shown in figure 5. The split circular ducts provide a larger contact interface area with the heat pipe evaporators as opposed to a single circular duct. Each cooling loop includes a pump and a bellows accumulator.

\section{Analytical Model}

The design of the Brayton HRS depends on many parameters. An Microsoft Excel (Microsoft Corporation, Inc.) spreadsheet model, called HRS-Opt, was developed to evaluate the design trade space described in the previous design study (ref. 1). For the analysis presented in this paper, the HRS-Opt spreadsheet model was modified to accommodate the FSPS HRS design.

The fin efficiency is a critical part of this analysis since it varies widely with heat pipe spacing and facesheet thickness. A closed-form equation for fin efficiency was available in the literature (ref. 2) and was adopted in HRSOpt, as discussed in the previous design study. In order to verify the accuracy of this equation and its applicability to the panel configuration, a detailed Finite-Difference model of a single heat pipe and half radiator fin was generated using SINDA FLUINT. The heat pipe spacing and fin thickness were varied and the results of the finite-difference model were compared to HRS-Opt. There was very good agreement between the HRS-Opt based fin efficiency calculations and the SINDA FLUINT model results (ref. 1).

The calculation of fluid loop system pressure drop is based on the simple flow geometry and a closed form fluid loop pressure drop calculation is possible. A simple equation, $\left[\Delta P=f^{*}(L / d) * \rho *\left(u^{2} / 2\right)\right]$ was used to calculate the system pressure drop in the coolant duct (ref. 3).

For the lunar application, the calculation of the radiator equivalent sink temperatures was necessary. A location on the equator of the moon was chosen for a few reasons. First, the sun would be parallel to the radiating surfaces and secondly, it's a more desirable location to abort a mission from. It is also the worst case scenario for the sink temperatures.

Two methods of calculating the radiator equivalent sink temperatures were considered. First, an equation for equivalent sink temperatures was available in the literature (ref. 4) and was used to predict radiator equivalent sink temperatures for Z-93 coating with 0.90 emittance, 0.20 absorptivity, and with $1.365 \mathrm{~kW} / \mathrm{m}^{2}$ solar insolation. Figure 6 shows the variation in lunar surface temperature and equivalent sink temperatures for both vertical and horizontal radiators based on the derived equation in the literature (ref. 4). The maximum sink temperature is $318 \mathrm{~K}$ and $270 \mathrm{~K}$ respectively for the vertical and horizontal configurations.

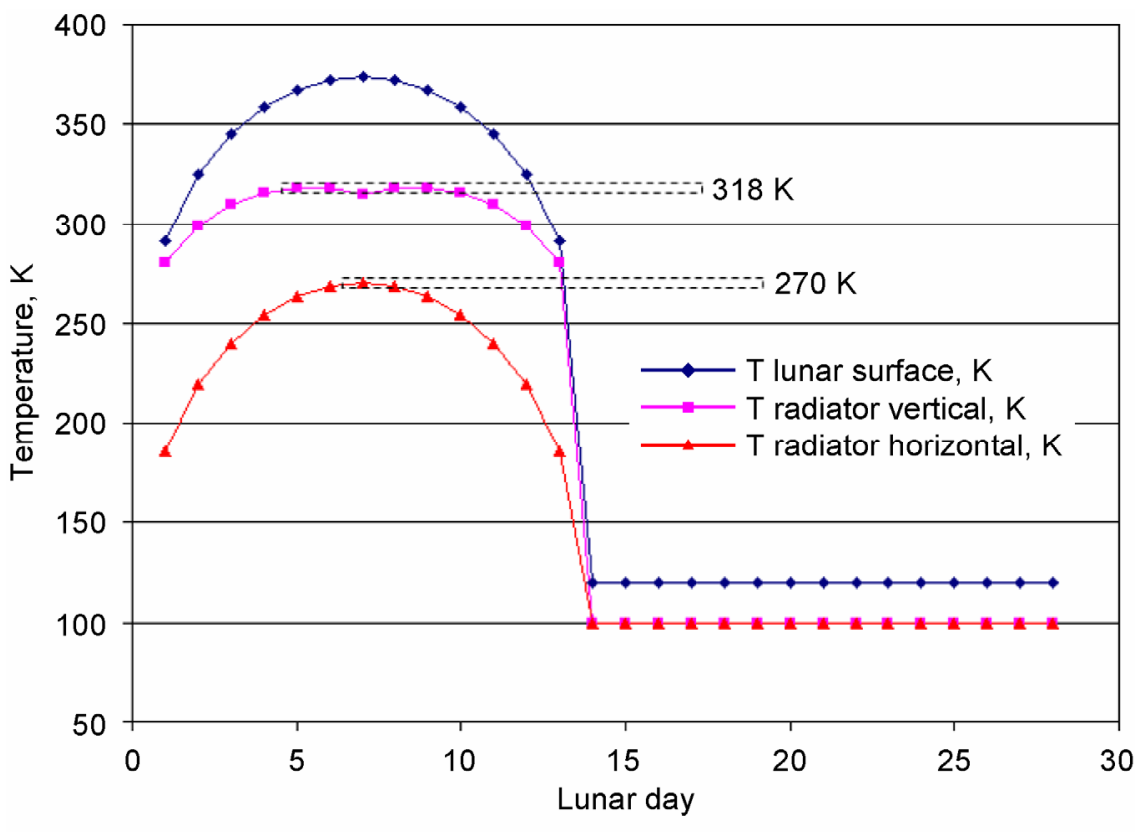

Figure 6.-Equation derived radiator equivalent sink temperatures. 
Second, in order to verify the accuracy of the equation, a detailed model of the radiator was generated using Thermal Desktop (Cullimore and Ring Technologies, Inc.). The model predicted radiator equivalent sink temperatures for the same assumptions and for a variety of radiator heights from the lunar surface. Sink temperature may be reduced by placing Multi-Layer Insulation (MLI) directly on the lunar surface beneath the radiator. The effect of MLI was analyzed for the vertical configuration. Figure 7 shows the MLI dimensions and location on the lunar surface with respect to the radiator. For the horizontal configuration, MLI has no effect on the sink temperatures due to the radiator orientation and view to space.

Figure 8 shows the results of the Thermal Desktop model. The maximum sink temperature for the vertical configuration varies as a function of radiator height from lunar surface from $318 \mathrm{~K}$ to $221 \mathrm{~K}$ for heights of 0.7 to $6 \mathrm{~m}$ respectively. The maximum sink temperature for the horizontal configuration is $270 \mathrm{~K}$ and is independent of radiator height from the lunar surface due to its orientation and view to space.

There was very good agreement between the equation-based calculations and the Thermal Desktop calculations. Thermal Desktop sink temperature results for the vertical radiator without MLI and for the horizontal radiator were within 1 percent of the calculations from the literature equation.

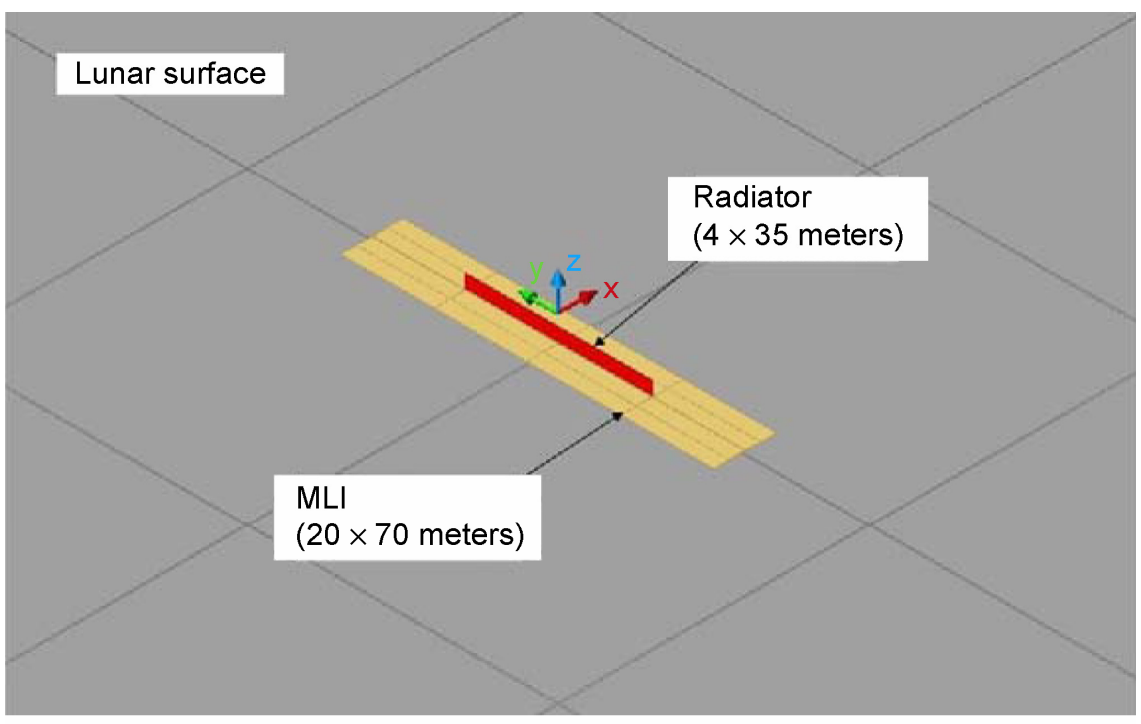

Figure 7.-Multi layer insulation dimensions and location on the lunar surface.

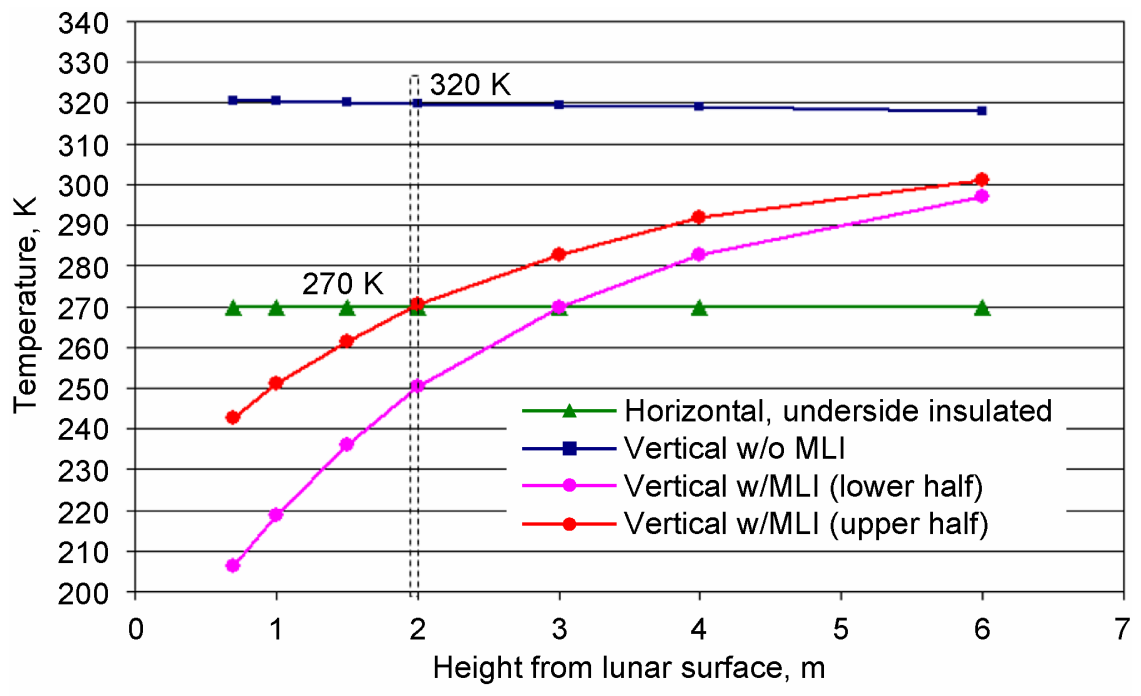

Figure 8.-Thermal desktop derived radiator equivalent sink temperatures. 
It is notable, that for the case of vertical radiator orientation with MLI on the lunar surface, the equivalent sink temperatures for the upper and lower sections of the radiator are different and vary as a function of radiator height from lunar surface. This difference becomes smaller as the radiator is moved further from the lunar surface. For vertical radiator orientation where the radiator will be relatively close to the lunar surface, and MLI is used, the direction of the coolant flow path within the radiator (upper to lower section, lower to upper section) will effect the radiator performance and therefore the HRS mass.

\section{HRS Design Parameters}

The Brayton HRS described in the previous design study (ref. 1) provided a starting point for the primary thermal design requirements and overall configuration. These parameters were updated as needed to accommodate the FSPS HRS design. The major design variables were radiator orientation (horizontal, vertical (with and without MLI)), coolant flow (series, parallel), radiator area, facesheet thickness, and duct diameter.

The heat pipes were assumed to use water with a 10 percent liquid fill fraction. The assumed heat pipe containment was titanium $\left(4.5 \mathrm{~g} / \mathrm{cm}^{3}\right)$. The thermal saddles were assumed to be made of $0.54 \mathrm{~g} / \mathrm{cm}^{3}$ POCO graphite. The facesheets were carbon-carbon (C-C) with a density of $1.92 \mathrm{~g} / \mathrm{cm}^{3}$ and thermal conductivity (normal to the direction of the heat pipes) of $239 \mathrm{~W} / \mathrm{m}-\mathrm{K}$ at $500 \mathrm{~K}$ and which varies as a function of temperature. The coolant duct was titanium with wall-thickness of $0.15 \mathrm{~cm}$.

Other design variables considered in this study were radiator heat load, and radiator inlet and outlet temperatures. For the vertical radiator configuration, MLI was introduced as a variable. In addition, because the upper and lower radiator sections have different equivalent sink temperatures for the MLI case, the direction of the coolant flow (from upper to lower section and from lower to upper section) was also introduced as a variable for this case.

The design parameters considered and their values or range of values is provided in table 1. For the vertical radiator configuration, the three different flow configurations (parallel, series - upper to lower, series-lower to upper) are presented graphically in figure 9 . The primary output parameter of interest was the total HRS mass. The total HRS mass includes the radiator panel mass, and the fluid loop mass with ducts, pumps, accumulators, and other miscellaneous components such as flexible fluid joints.

TABLE 1.-DESIGN PARAMETERS AND VARIABLES USED IN STUDY

\begin{tabular}{|c|c|}
\hline Parameter & Value/Range \\
\hline Pump efficiency (\%) & 30 \\
\hline Fluid duct pressure drop $(\mathrm{kPa})$ & 100 \\
\hline Duct wall-thickness $(\mathrm{cm})$ & 0.15 \\
\hline Heat pipe spacing $(\mathrm{cm})$ & 10 \\
\hline Heat pipe length $(\mathrm{cm})$ & 200 \\
\hline Heat pipe inner diameter $(\mathrm{cm})$ & 1.86 \\
\hline HP tube wall thickness $(\mathrm{cm})$ & 0.07 \\
\hline Heat pipe saddle min. thickness $(\mathrm{cm})$ & 0.375 \\
\hline Evaporator radial flux limit $\left(\mathrm{W} / \mathrm{cm}^{2}\right)$ & 10 \\
\hline Carbon-carbon in-plane thermal conductivity $(\mathrm{W} / \mathrm{m}-\mathrm{K})$ & Function of temperature \\
\hline Radiator orientation & Variable \\
\hline Coolant flow & Variable \\
\hline Radiator area $\left(\mathrm{m}^{2}\right)$ & Variable (included 10 percent margin) \\
\hline Facesheet thickness $(\mathrm{cm})$ & Variable \\
\hline Duct diameter $(\mathrm{cm})$ & Variable \\
\hline Radiator heat load (kWt) & $81(25 \mathrm{kWe}), 155(50 \mathrm{kWe}), 297(100 \mathrm{kWe})$ \\
\hline Radiator inlet temperature $(\mathrm{K})$ & $507(25 \mathrm{kWe}), 510(50 \mathrm{kWe}), 512(100 \mathrm{kWe})$ \\
\hline Radiator exit temperature $(\mathrm{K})$ & 386 \\
\hline Radiator orientation & Horizontal, Vertical (with and without MLI) \\
\hline Coolant flow & Series, Parallel \\
\hline Coolant flow direction & Upper to lower section, Lower to upper section \\
\hline
\end{tabular}




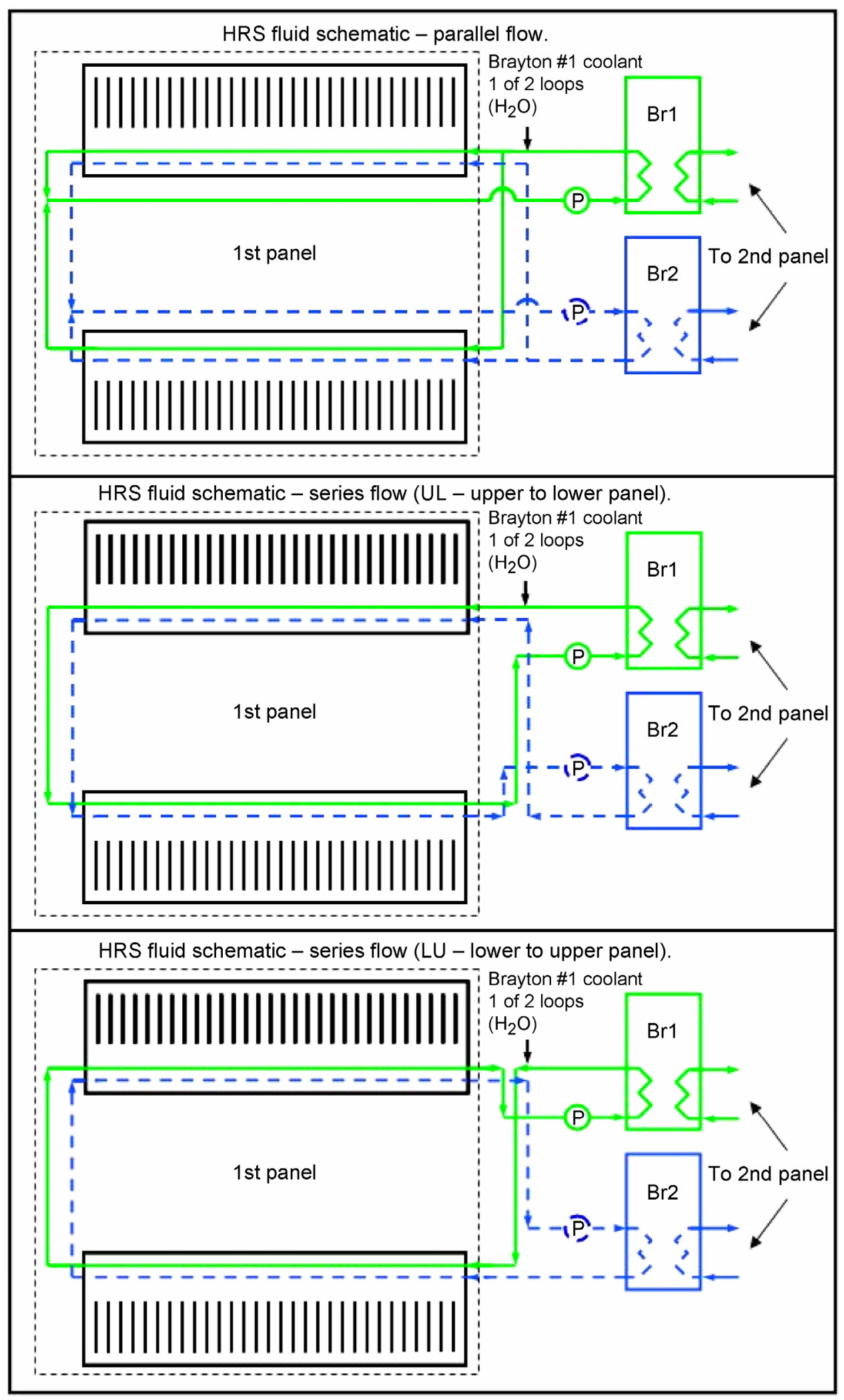

Figure 9.-Vertical radiator - coolant flow configurations. 


\section{Analytical Results}

The process used to analyze each configuration was as follows. For a given power level $(25,50,100 \mathrm{kWe})$ the corresponding radiator heat load $(81,155,297 \mathrm{kWt})$ and radiator inlet and outlet temperatures $(507 / 386,510 / 386$, $512 / 386 \mathrm{~K}$ ) were chosen. For each of these cases, 3 radiator configurations (horizontal, vertical with MLI, vertical without MLI) were analyzed. For the horizontal, and the vertical without MLI configurations, 2 coolant flow paths (parallel, series) were analyzed. For the vertical with MLI configuration, 3 coolant flow paths (parallel, series upper to lower section, series lower to upper section) were analyzed. Seven cases were analyzed for each power level, as shown in table 2.

TABLE 2.-CASES ANALYZED FOR EACH CONVERTER OUTPUT

\begin{tabular}{|l|c|c|c|c|c|c|c|}
\hline Radiator orientation & Horizontal & Horizontal & Vertical & Vertical & Vertical & Vertical & Vertical \\
\hline MLI on moon surface & NO & NO & NO & NO & YES & YES & YES \\
\hline Coolant flow path & Parallel & Series & Parallel & Series & Parallel & Series & Series \\
\hline $\begin{array}{l}\text { Coolant flow path for series, Upper to } \\
\text { Lower (UL) or Lower to Upper (LT) }\end{array}$ & NA & NA & NA & NA & NA & UL & LU \\
\hline
\end{tabular}

The radiator area and facesheet thickness were adjusted until the radiator coolant exit temperature reached the required value and the radiator heat load matched the required value. At the same time, the duct size and heat pipe evaporator length were varied to achieve the assigned system pressure drop $(100 \mathrm{kPa})$ and the $10 \mathrm{~W} / \mathrm{cm}^{2}$ evaporator radial flux limit respectively.

A sample case for a vertical radiator, with series coolant flow path from upper to lower panel, with MLI on lunar surface is reported in table 3 for $10 \mathrm{~cm}$ heat pipe spacing and a $1.86 \mathrm{~cm}$ heat pipe inner diameter. The resulting facesheet thickness required to achieve the $386 \mathrm{~K}$ radiator exit temperature was $0.21 \mathrm{~mm}$. The heat pipe geometry and facesheet thickness resulted in a fin efficiency of 76.2 percent. The required pump system pressure drop was set at $100 \mathrm{kPa}$ which resulted in a pump power of $110 \mathrm{~W}$ for each pump. The maximum heat pipe power and radial flux was $733 \mathrm{~W}$ and $10 \mathrm{~W} / \mathrm{cm}^{2}$, respectively. The total HRS mass was $829.1 \mathrm{~kg}$ or $5.4 \mathrm{~kg} / \mathrm{m}^{2}$ (based on total surface area), and the radiator panel areal mass was $3.8 \mathrm{~kg} / \mathrm{m}^{2}$ (based on total surface area).

TABLE 3.-SAMPLE RESULTS CASE

\begin{tabular}{|c|c|c|}
\hline Parameter & Value & Basis \\
\hline Electrical power $(\mathrm{kWe})$ & 100 & Input \\
\hline Thermal power $(\mathrm{kWt})$ & 297 & Input \\
\hline Coolant inlet temp. (K) & 512 & Input \\
\hline Coolant outlet temp. (K) & 386 & Input \\
\hline Heat pipe spacing $(\mathrm{cm})$ & 10 & Input \\
\hline Heat pipe inner diameter $(\mathrm{cm})$ & 1.86 & Input \\
\hline Facesheet thickness (mm) & 0.21 & Input \\
\hline Pump system pressure drop $(\mathrm{kPa})$ & 100 & Input \\
\hline Fin efficiency $(\%)$ & 76.2 percent & Calculated \\
\hline Total pump power (watts) & 110 & Calculated \\
\hline MAX heat pipe power (watts) & 733 & Calculated \\
\hline MAX heat pipe radial flux $\left(\mathrm{W} / \mathrm{cm}^{2}\right)$ & 10 & Calculated \\
\hline Total radiator panel mass $(\mathrm{kg})$ & 575.9 & Calculated \\
\hline Total heat transport mass (with pumps and accumulators) (kg) & 236.9 & Calculated \\
\hline Total HRS mass $(\mathrm{kg})$ & 829.1 & Calculated \\
\hline Radiator panel areal mass-single sided $\left(\mathrm{kg} / \mathrm{m}^{2}\right)$ & 3.8 & Calculated \\
\hline Total HRS areal mass-single sided $\left(\mathrm{kg} / \mathrm{m}^{2}\right)$ & 5.4 & Calculated \\
\hline
\end{tabular}

Figure 10 shows the variance of the HRS total mass as a function of power level for the different radiator configurations with a heat pipe spacing of $10 \mathrm{~cm}$, heat pipe inner diameter of $1.86 \mathrm{~cm}$ and pump system pressure drop of $100 \mathrm{kPa}$. Results show that the minimum mass HRS occurs for a vertical radiator with MLI on the lunar surface with coolant flow in series from the upper radiator panel to the lower panel. The benefit of upper to lower panel coolant flow path is more pronounced at higher power levels. For the vertical configuration, adding MLI on the lunar surface reduces the HRS total mass by as much as 33 percent. 


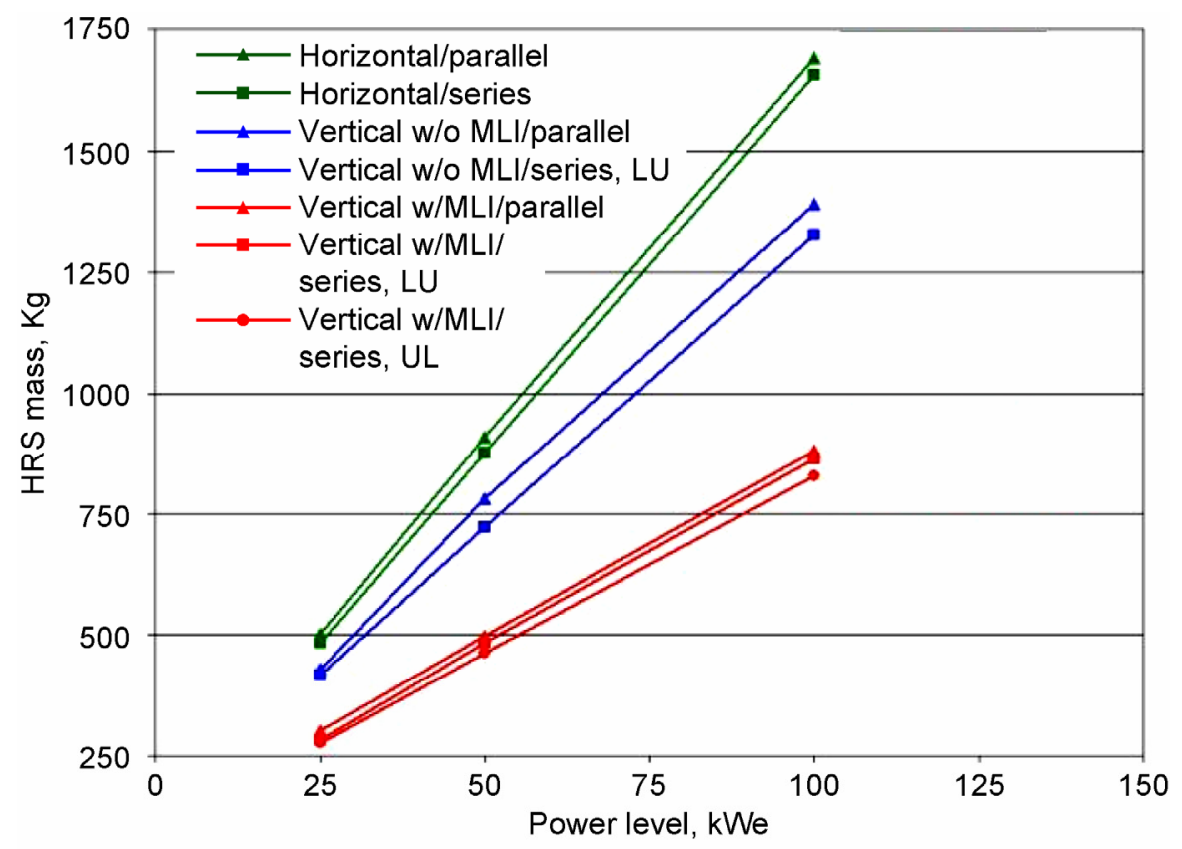

Figure 10.-HRS mass versus power level.

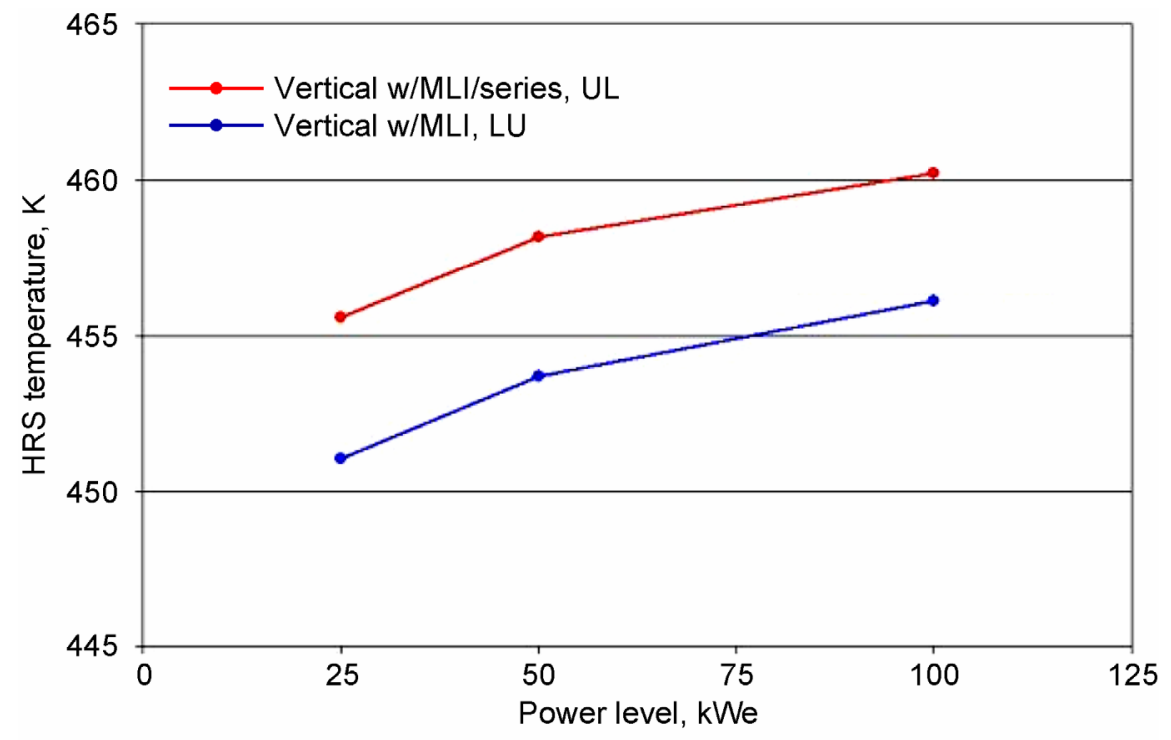

Figure 11.-HRS radiator temperature versus power level.

Figure 11 shows the HRS average radiator temperature as a function of power level for two different coolant flow paths. This is for a vertical radiator configuration with MLI on the lunar surface with heat pipe spacing of $10 \mathrm{~cm}$, heat pipe inner diameter of $1.86 \mathrm{~cm}$ and pump system pressure drop of $100 \mathrm{kPa}$. Results show that the radiator with coolant flow from the upper to the lower panel is warmer by about $5 \mathrm{~K}$ due to its corresponding warmer sink temperature as shown earlier (fig. 8). A higher temperature radiator is more efficient, and as shown in figure 10, results in 4 to 5 percent mass savings; $14 \mathrm{~kg}$ for the $25 \mathrm{kWe}$ power level, $21 \mathrm{~kg}$ for the $50 \mathrm{kWe}$ power level, and $35 \mathrm{~kg}$ mass for the $100 \mathrm{kWe}$ power level, for this configuration and flow path.

Figures 12 and 13 show the variance of the HRS radiator physical and radiative area respectively, as a function of power level for a heat pipe spacing of $10 \mathrm{~cm}$, heat pipe inner diameter of $1.86 \mathrm{~cm}$ and pump system pressure drop of $100 \mathrm{kPa}$. The horizontal radiator has a physical area equal to its radiative area, while the vertical radiator has a radiative area equal to twice its physical area. This is because the horizontal radiator radiates only from its upward facing surface, while the vertical radiator radiates from both sides. Figure 12 shows the variance of the HRS 


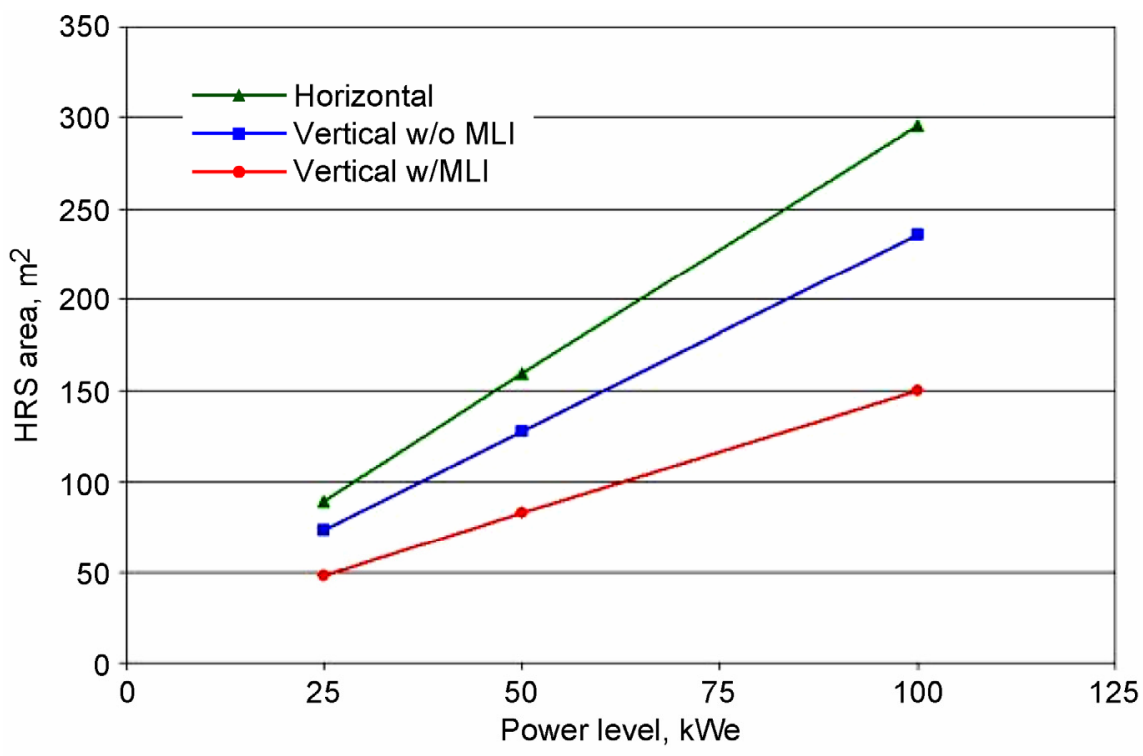

Figure 12.-HRS radiator physical area versus power level.

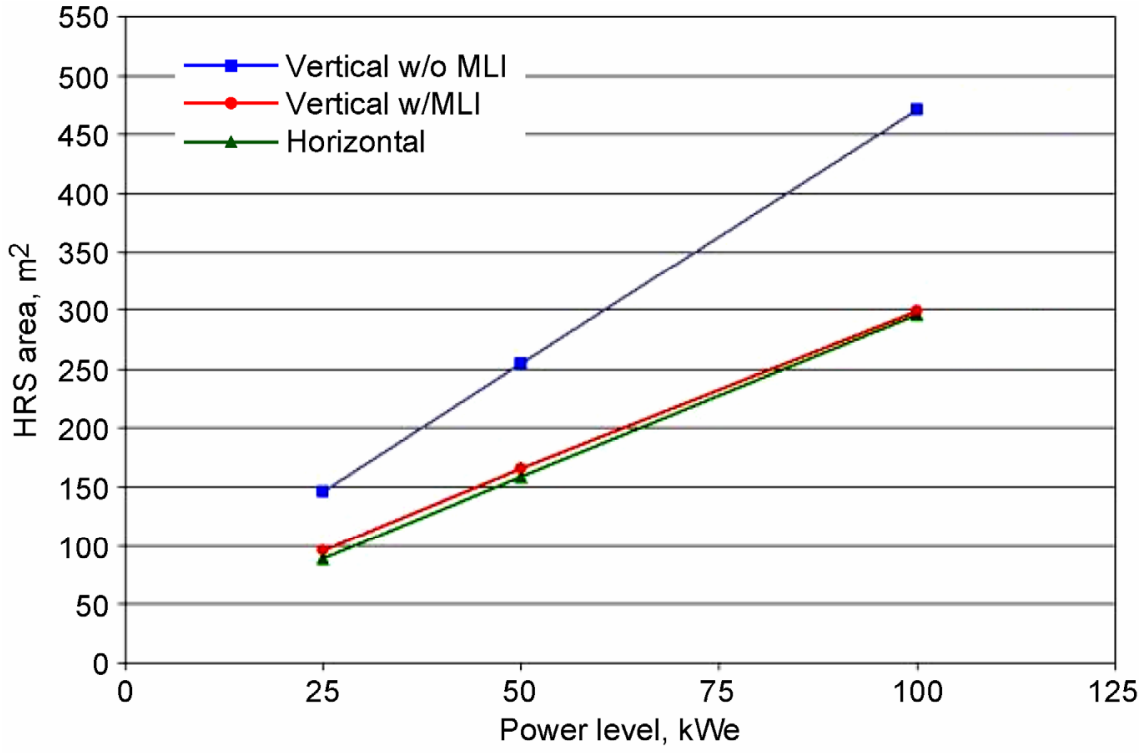

Figure 13.-HRS radiator radiative area versus power level.

physical area as a function of power level, and figure 13 shows the variance of the HRS radiative area as a function of power level. Results show that the HRS radiator physical area is greatest for the horizontal orientation and least for the vertical with MLI on the lunar surface. Adding MLI on the lunar surface reduces the vertical radiator's area by about 35 percent. When radiative areas are compared, it is the vertical without MLI configuration that requires the largest area (in combination with its corresponding sink temperature and view factors) to reject the required amount of heat as shown in figure 13. Horizontal and vertical with MLI configurations require about the same radiative area.

Figure 14 shows the variance of the HRS radiator areal mass as a function of power level for a heat pipe spacing of $10 \mathrm{~cm}$, heat pipe inner diameter of $1.86 \mathrm{~cm}$ and pump system pressure drop of $100 \mathrm{kPa}$. Results show that the horizontal configuration has a much higher areal mass than either one of the vertical configurations. Areal masses for the vertical configurations are about the same. 


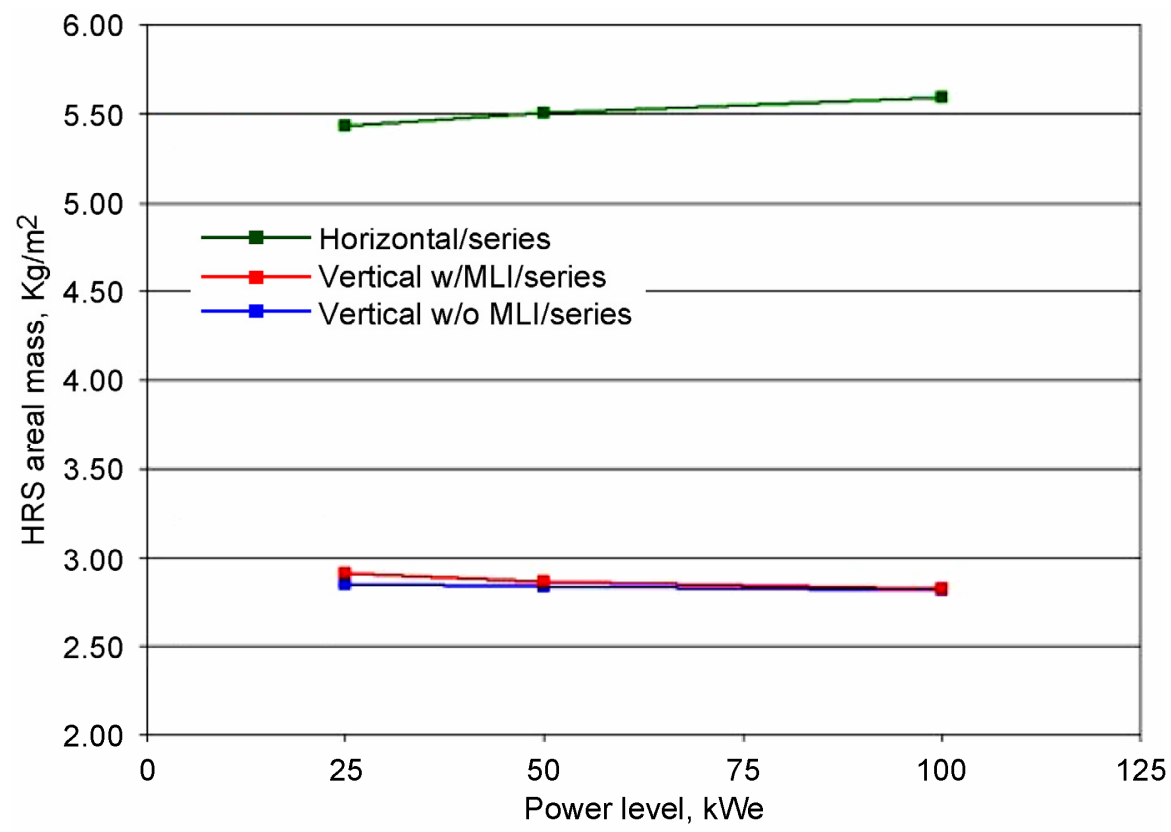

Figure 14.-HRS areal mass versus power level.

\section{Conclusions}

The interplay between radiator orientations, coolant flow paths, and the addition of MLI to the lunar surface was examined for various power levels of a Fission Surface Power System on the moon. Based on the results of this paper, there is substantial area and mass savings for a FSPS HRS in a vertical orientation utilizing MLI on the lunar surface. For the vertical orientation, adding MLI on the lunar surface reduces the radiator area by about 35 percent and the HRS total mass by about 33 percent as compared to a horizontal radiator configuration. A coolant flow path configuration from the upper radiator panel to the lower panel results in an additional 4 to 5 percent mass savings. Additional trade studies are needed to further refine the FSPS HRS design.

\section{References}

1. Siamidis, J., Mason, L., "Heat Rejection Concepts for Brayton Power Conversion Systems," AIAA-2004-5654, NASA/TM-2005-2133372005.

2. Gilmore, D.G., Satellite Thermal Control Handbook, The Aerospace Corporation Press, El Segundo, California, 1994, pp. 133.

3. J.P. Holman, Heat Transfer, 5th Edition, McGraw-Hill, 1981, pp. 210-211.

4. Dallas, T., Diaguila, A., Saltman, J., "Design Studies on the Effects of Orientation, Lunation, and Location on the Performance of Lunar Radiators," NASA TM X-1846. 


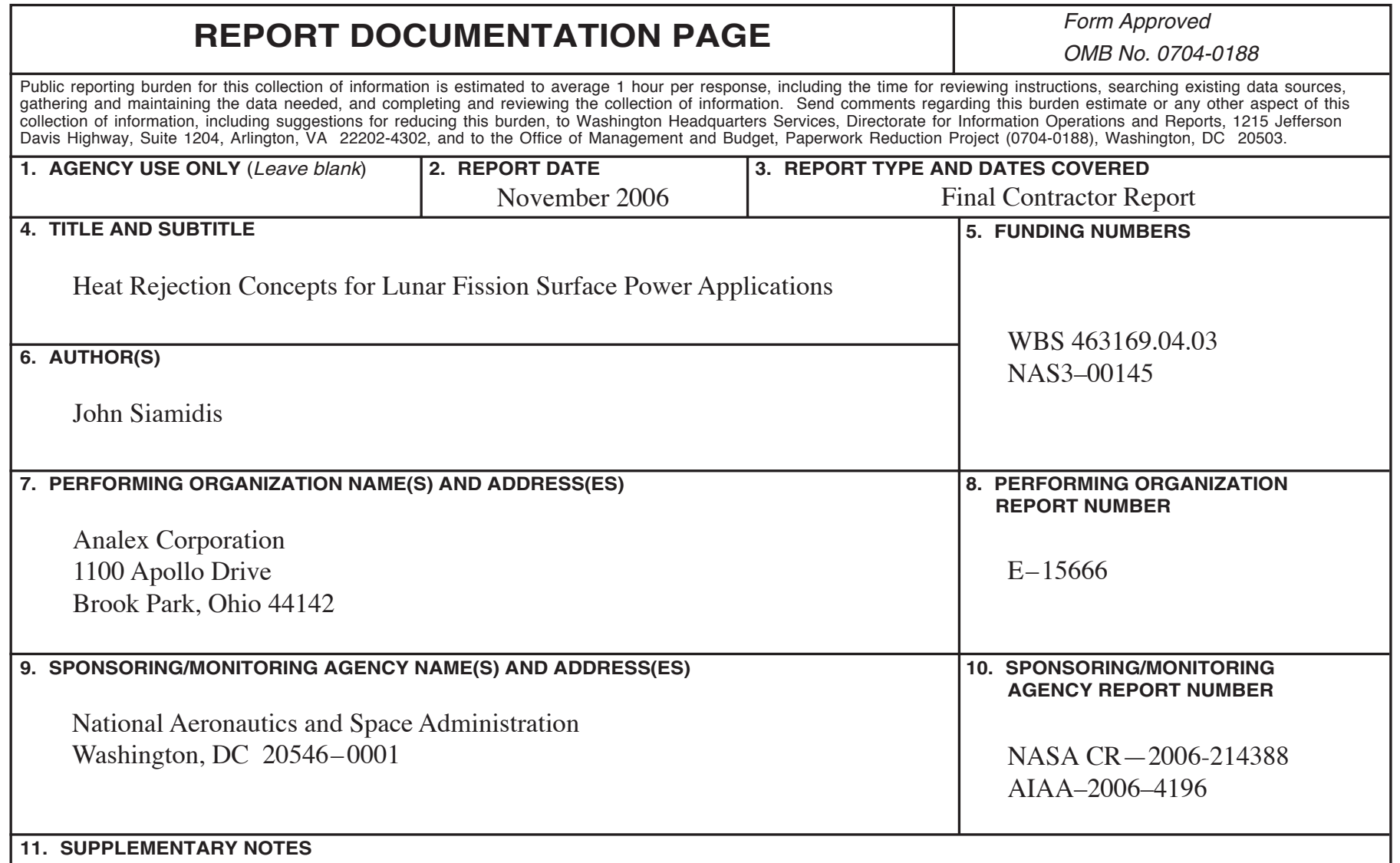

Prepared for the Fourth International Energy Conversion Engineering Conference and Exhibit (IECEC) sponsored by the American Institute of Aeronautics and Astronautics, San Diego, California, June 26-29, 2006. Responsible person, John Siamidis, organization code RPT, 216-433-3151.

12a. DISTRIBUTION/AVAILABILITY STATEMENT

12b. DISTRIBUTION CODE

Unclassified - Unlimited

Subject Category: 20

Available electronically at http://gltrs.grc.nasa.gov

This publication is available from the NASA Center for AeroSpace Information, 301-621-0390.

13. ABSTRACT (Maximum 200 words)

This paper describes potential heat rejection design concepts for lunar surface Brayton power conversion systems. Brayton conversion systems are currently under study by NASA for surface power applications. Surface reactors may be used for the moon to power human outposts enabling extended stays and closed loop life support. The Brayton Heat Rejection System (HRS) must dissipate waste heat generated by the power conversion system due to inefficiencies in the thermal-toelectric conversion process. Space Brayton conversion system designs tend to optimize at efficiencies of about 20 to 25 percent with radiator temperatures in the $400 \mathrm{~K}$ to $600 \mathrm{~K}$ range. A notional HRS was developed for a $100 \mathrm{kWe}-\mathrm{class}$ Brayton power system that uses a pumped water heat transport loop coupled to a water heat pipe radiator. The radiator panels employ a tube and fin construction consisting of regularly-spaced circular heat pipes contained within two composite facesheets. The water heat pipes interface to the coolant through curved sections partially contained within the cooling loop. The paper evaluates various design parameters including radiator panel orientation, coolant flow path, and facesheet thickness. Parameters were varied to compare design options on the basis of $\mathrm{H}_{2} \mathrm{O}$ pump pressure rise and required power, heat pipe unit power and radial flux, radiator area, radiator panel areal mass, and overall HRS mass.

14. SUBJECT TERMS 15. NUMBER OF PAGES

Heat rejection; Radiator; Brayton power; Conversion; Heat pipes 18

\begin{tabular}{|c|c|c|}
\hline $\begin{array}{c}\text { 17. SECURITY CLASSIFICATION } \\
\text { OF REPORT } \\
\text { Unclassified }\end{array}$ & $\begin{array}{c}\text { 18. SECURITY CLASSIFICATION } \\
\text { OF THIS PAGE } \\
\text { Unclassified }\end{array}$ & $\begin{array}{c}\text { 19. SECURITY CLASSIFICATION } \\
\text { OF ABSTRACT } \\
\text { Unclassified }\end{array}$ \\
\hline
\end{tabular}

NSN 7540-01-280-5500

Standard Form 298 (Rev. 2-89)

Prescribed by ANSI Std. Z39-18 298-102 

